\title{
A Short and Efficient Synthesis of a Vinyl Substituted Tricyclic Erythromycin Derivative
}

\author{
Robert F. Keyes*, Justin J. Carter, Xiaolin Zhang and \\ Zhenkun Ma
}

Infectious Disease Research, Abbott Laboratories, D47N, AP52

200 Abbott Park Road, Abbott Park, Illinois 60064-6217

robert.keyes@abbott.com<smiles>CSCCC(N)CO</smiles>

(S)-4-Methylsulfonyl- $N$-( $t$-butoxycarbonyl)-2-amino-1-butanol

(6). $\quad N$-(t-butoxycarbonyl)-methionine $(10 \mathrm{~g}, 40.1 \mathrm{mmol})$ was dissolved in anhydrous THF $(200 \mathrm{~mL})$ and cooled to $-10^{\circ} \mathrm{C}$. This was treated with $\mathrm{N}$-methylmorpholine $(4.4 \mathrm{~mL}, 40.1 \mathrm{mmol})$ followed by ethyl chloroformate $(3.8 \mathrm{~mL}, 40.1 \mathrm{mmol})$ to form the mixed anhydride. It was then treated with sodium borohydride $(4.6 \mathrm{~g}, 120.3 \mathrm{mmol})$ and stirred at $-10^{\circ} \mathrm{C}$ for $10 \mathrm{~min}$. The reaction was warmed to $0^{\circ} \mathrm{C}$, treated with $\mathrm{MeOH}(400 \mathrm{~mL})$ over $20 \mathrm{~min}$, and stirred at $0^{\circ} \mathrm{C}$ for $25 \mathrm{~min}$. The reaction was then neutralized with $1 \mathrm{M} \mathrm{KHSO}_{4}(150 \mathrm{~mL})$ and concentrated in vacuo. The residue was extracted with EtOAc $(3 \times 200 \mathrm{~mL})$. The combined extracts were washed with $\left.1 \mathrm{M} \mathrm{KHSO}_{4}(1 \times 200 \mathrm{~mL}), \mathrm{H}_{2} \mathrm{O}\right)(1 \times 200 \mathrm{~mL})$, sat $\mathrm{NaHCO}_{3}(1 \times 200 \mathrm{~mL})$, and brine $(1 \times 200 \mathrm{~mL})$. The organic layer was dried $\left(\mathrm{Na}_{2} \mathrm{SO}_{4}\right)$, filtered, and the solvent removed in vacuo to give $8.02 \mathrm{~g} \mathrm{(83 \% )} \mathrm{of} \mathbf{6}$ as a colorless oil. It was used in the next step without purification. ${ }^{1} \mathrm{H}$ NMR $\left(300 \mathrm{MHz}, \mathrm{CDCl}_{3}\right) \delta \mathrm{ppm} 1.45$ $(\mathrm{s}, 9 \mathrm{H}) 1.80(\mathrm{~m}, 2 \mathrm{H}) 2.11(\mathrm{~s}, 3 \mathrm{H}) 2.56(\mathrm{~m}, 2 \mathrm{H}) 2.99(\mathrm{t}, J=3.22 \mathrm{~Hz}, 1 \mathrm{H}) 3.68(\mathrm{~m}, 3 \mathrm{H})$ $4.86(\mathrm{~d}, J=7.80 \mathrm{~Hz}, 1 \mathrm{H}) ; \mathrm{MS} m / z$ (ESI) $236.1(\mathrm{M}+\mathrm{H})^{+}$.<smiles>CS(=O)CCC(CO)NC(=O)O</smiles>

(S)-(1-Hydroxymethyl-3-methanesulfonyl-propyl)-carbamic-tbutyl ester (7). Compound 6 (9.89 g, $42.1 \mathrm{mmol})$ was dissolved in $\mathrm{MeOH}(125 \mathrm{~mL})$ and cooled to $0^{\circ} \mathrm{C}$. It was then treated with a solution of sodium periodate $(9.0 \mathrm{~g}, 42.1 \mathrm{mmol})$ dissolved in $\mathrm{H}_{2} \mathrm{O}(42$ $\mathrm{mL}$ ) slowly not letting the temperature exceed $10^{\circ} \mathrm{C}$. A thick white precipitate formed. The reaction was stirred at $0^{\circ} \mathrm{C}$ for $3 \mathrm{hr}$ then at room temperature for $1 \mathrm{hr}$. The reaction was then filtered through a pad of Celite and the filtrate was concentrated in vacuo and EtOAc $(100 \mathrm{~mL})$ added. The layers were separated and the organic layer was dried $\left(\mathrm{Na}_{2} \mathrm{SO}_{4}\right)$, filtered, and the solvent removed in vacuo to give $9.6 \mathrm{~g}(91 \%)$ of 7 as a colorless oil. This was used in the next step without purification. ${ }^{1} \mathrm{H}$ NMR $(500 \mathrm{MHz}$, DMSO-D6) $\delta \mathrm{ppm} 1.38(\mathrm{~s}, 9 \mathrm{H}) 2.51(\mathrm{~d}, J=4.88 \mathrm{~Hz}, 3 \mathrm{H}) 2.77(\mathrm{~m}, 2 \mathrm{H}) 3.75(\mathrm{~m}, 2 \mathrm{H})$ $4.62(\mathrm{~s}, 1 \mathrm{H}) 4.67(\mathrm{~m}, J=5.19,5.19 \mathrm{~Hz}, 2 \mathrm{H}) 6.47(\mathrm{~s}, 1 \mathrm{H}) 6.60(\mathrm{~d}, J=8.54 \mathrm{~Hz}, 1 \mathrm{H})$; MS $m / z(\mathrm{ESI}) 252.1(\mathrm{M}+\mathrm{H})^{+}$. 
NHBoc (S)-N-Boc-2-amino-3-butenol (10) from 7. Compound 7 (14.7 g, 58.4
mmol) was dissolved in 1,2-dichlorobenzene $(500 \mathrm{~mL})$ and treated with sodium acetate $(39.7 \mathrm{~g}, 292.1 \mathrm{mmol})$. The reaction was then heated to $170^{\circ} \mathrm{C}$ for $16 \mathrm{hr}$. The reaction mixture was filtered through a pad of Celite and the filtrate concentrated in vacuo. The residue was purified by flash chromatography $\left(100 \mathrm{Et}_{2} \mathrm{O}\right)$ to give $5.0 \mathrm{~g}(46 \%)$ of 10 as an oil. ${ }^{1} \mathrm{H}$ NMR $\left(300 \mathrm{MHz}, \mathrm{CDCl}_{3}\right) \delta \mathrm{ppm} 1.43(\mathrm{~s}, 9 \mathrm{H}) 2.28(\mathrm{~d}, J=5.43 \mathrm{~Hz}, 1 \mathrm{H})$ $3.65(\mathrm{~d}, J=5.43 \mathrm{~Hz}, 2 \mathrm{H}) 4.25(\mathrm{~s}, 1 \mathrm{H}) 5.25(\mathrm{~d}, J=1.36 \mathrm{~Hz}, 2 \mathrm{H}) 5.78(\mathrm{~m}, 1 \mathrm{H}) ;{ }^{13} \mathrm{C} \mathrm{NMR}$ $\left(500 \mathrm{MHz}, \mathrm{CDCl}_{3}\right) \delta 28.2,49.5,65.1,79.9,116.7 .135 .5 ; \mathrm{MS} m / z(\mathrm{ESI}) 188.1(\mathrm{M}+\mathrm{H})^{+}$.

(S)- $N$-(t-Butoxycarbonyl)-2,3,4-trimethyl-4-vinyl-3-oxazolidinone (9).
Methyltriphenylphosphonium bromide $(39.30 \mathrm{~g}, 110 \mathrm{mmol})$ was suspended bis(trimethylsilyl)amide (220 mL, $110 \mathrm{mmol}, 0.5 \mathrm{M}$ in toluene). The yellow solution was stirred at room temperature for $1 \mathrm{hr}$ then it was cooled to $-78^{\circ} \mathrm{C}$ and treated with a solution of (R)-Garner's aldehyde (8.34 g, $36.4 \mathrm{mmol})$ dissolved in anhydrous THF (160 $\mathrm{mL}$ ) by slow addition. The reaction was then allowed to stir at room temperature for 3.5 $\mathrm{hr}$. The reaction was quenched by the addition of $\mathrm{MeOH}(80 \mathrm{~mL})$. The reaction was partitioned between saturated sodium potassium tartrate and $\mathrm{H}_{2} \mathrm{O}(1000 \mathrm{~mL})$. The layers were separated and the aqueous layer was extracted with $\mathrm{Et}_{2} \mathrm{O}(2 \times 500 \mathrm{~mL})$. The combined organic layers were then washed with brine $(1 \times 250 \mathrm{~mL})$. The organic layer was dried $\left(\mathrm{MgSO}_{4}\right)$, filtered, and the solvent removed in vacuo to give $20 \mathrm{~g}$ of crude product, which was triturated with $\mathrm{Et}_{2} \mathrm{O}$ to give $10.3 \mathrm{~g}$ of material. Purification by flash chromatography (95 hexanes / 5 EtOAc) gave $6.6 \mathrm{~g}(80 \%)$ of 9 as an oil. ${ }^{1} \mathrm{H}$ NMR (300 $\left.\left.\mathrm{MHz}_{\mathrm{CDCl}}\right)\right) \delta \mathrm{ppm} 1.48(\mathrm{~d}, \mathrm{~J}=19.33 \mathrm{~Hz}, 9 \mathrm{H}) 1.60(\mathrm{~s}, 6 \mathrm{H}) 3.75(\mathrm{dd}, \mathrm{J}=8.82,2.37 \mathrm{~Hz}, 2$ H) $4.04(\mathrm{~m}, \mathrm{~J}=8.82,6.10 \mathrm{~Hz}, 1 \mathrm{H}) 5.14(\mathrm{~d}, \mathrm{~J}=9.83 \mathrm{~Hz}, 2 \mathrm{H}) 5.81(\mathrm{~m}, 1 \mathrm{H}) ;{ }^{13} \mathrm{C} \mathrm{NMR}(500$ $\left.\mathrm{MHz}, \mathrm{CDCl}_{3}\right)$ 28.24, 59.54, 67.98, 7657, 76.99, 115.58, 137.23, 151.80; MS m / z (ESI) $228.1(\mathrm{M}+\mathrm{H})^{+}$.

NHBoc (S)-N-Boc-2-amino-3-butenol (10) from 9. Compound 9 (3.3 g, 14.6
mmol) was dissolved in a $90 \%$ aqueous $\mathrm{MeOH}$ solution $(70 \mathrm{~mL})$. This was treated with Dowex-M43 ion exchange resin $(15 \mathrm{~g})$. The reaction was stirred at room temperature for $9 \mathrm{hr}$. The resin was removed by vacuum filtration. The mother liquors were then concentrated in vacuo to give $2.18 \mathrm{~g}(80 \%)$ of $\mathbf{1 0}$ as an oil. The material was used in the next step without purification. ${ }^{1} \mathrm{H} \mathrm{NMR}\left(300 \mathrm{MHz}, \mathrm{CDCl}_{3}\right) \delta$ ppm $1.43(\mathrm{~s}, 9 \mathrm{H}) 2.28(\mathrm{~d}, J=5.43 \mathrm{~Hz}, 1 \mathrm{H}) 3.65(\mathrm{~d}, J=5.43 \mathrm{~Hz}, 2 \mathrm{H}) 4.25(\mathrm{~s}, 1 \mathrm{H}) 5.25$ (d, $J=1.36 \mathrm{~Hz}, 2 \mathrm{H}) 5.78(\mathrm{~m}, 1 \mathrm{H}) ;{ }^{13} \mathrm{C} \mathrm{NMR}\left(500 \mathrm{MHz}, \mathrm{CDCl}_{3}\right) \delta$ 28.2,49.5, 65.1, 79.9,116.7.135.5; $\mathrm{MS} m / z(\mathrm{ESI}) 188.1(\mathrm{M}+\mathrm{H})^{+}$.

NHBoc (S)-(1-Azidomethyl-allyl)-carbamic acid-t-butyl ester (11). Compound 10 (2.03 g, $10.9 \mathrm{mmol})$ was dissolved in anhydrous $\mathrm{CH}_{2} \mathrm{Cl}_{2}(18 \mathrm{~mL})$ and cooled to $-10^{\circ} \mathrm{C}$. The solution was treated with diisopropylethyl amine $(2.08 \mathrm{~mL}, 11.9$ $\mathrm{mmol})$ followed by methanesulfonyl chloride $(0.924 \mathrm{~mL}, 11.9 \mathrm{mmol})$, which was added at such a rate so the temperature did not exceed $-5^{\circ} \mathrm{C}$. The reaction was stirred at $-10^{\circ} \mathrm{C}$ for $45 \mathrm{~min}$ then it was quenched with brine $(20 \mathrm{~mL})$. The layers were separated and the 
aqueous layer was extracted with $\mathrm{CH}_{2} \mathrm{Cl}_{2}(2 \times 25 \mathrm{~mL})$. The combined organic layers were washed with $1 \mathrm{M} \mathrm{KHSO}_{4}(1 \times 25 \mathrm{~mL})$, brine $(1 \times 25 \mathrm{~mL})$, sat $\mathrm{NaHCO}_{3}(1 \times 25 \mathrm{~mL})$, and brine $(1 \times 25 \mathrm{~mL})$. The organic layer was dried $\left(\mathrm{Na}_{2} \mathrm{SO}_{4}\right)$, filtered, and the solvent removed in vacuo. The residue was dissolved in anhydrous DMF $(30 \mathrm{~mL})$ and treated with sodium azide $(2.12 \mathrm{~g}, 33.6 \mathrm{mmol})$. The solution was heated to $60^{\circ} \mathrm{C}$ for $6 \mathrm{hr}$. The reaction was cooled and concentrated in vacuo. The residue was partitioned between EtOAc $(75 \mathrm{~mL})$ and brine $(75 \mathrm{~mL})$. The layers were separated and the aqueous layer was extracted with EtOAc $(2 \times 75 \mathrm{~mL})$. The combined organic layers were washed with brine $(1 \times 75 \mathrm{~mL})$ and dried $\left(\mathrm{Na}_{2} \mathrm{SO}_{4}\right)$. They were filtered and concentrated in vacuo. Purification by flash chromatography (10 $\mathrm{Et}_{2} \mathrm{O} / 90$ hexanes) gave $1.70 \mathrm{~g}$ (74\%) of $\mathbf{1 1}$ as an oil. ${ }^{1} \mathrm{H}$ NMR $\left(300 \mathrm{MHz}, \mathrm{CDCl}_{3}\right) \delta \mathrm{ppm} 1.45$ (d, J=8.14 Hz, $\left.9 \mathrm{H}\right) 1.57$ (s, $\left.2 \mathrm{H}\right) 3.45$ $(\mathrm{m}, 1 \mathrm{H}) 5.25(\mathrm{~d}, J=9.16 \mathrm{~Hz}, 2 \mathrm{H}) 5.82(\mathrm{~m}, 1 \mathrm{H}) ;{ }^{13} \mathrm{C} \mathrm{NMR}\left(500 \mathrm{MHz}, \mathrm{CDCl}_{3}\right) \delta$ 28.4,52.5,54.9,80.1,116.8,135.2; MS $m / z(\mathrm{ESI}) 213.1(\mathrm{M}+\mathrm{H})^{+}$.

$\mathrm{NH}_{2}$ (S)-Azidomethyl-allylamine (12). Compound 11 (1.70 g, $\left.8.04 \mathrm{mmol}\right)$ was treated with $4 \mathrm{~N} \mathrm{HCl}$ in dioxane $(11.2 \mathrm{~mL})$. The reaction was stirred at room temperature for $1 \mathrm{hr}$. The reaction was concentrated in vacuo. The residue was dissolved in acetonitrile and treated with Dowex-M43 ion exchange resin (10 g). It was stirred at room temperature for $22 \mathrm{hr}$ then the resin was removed by filtration. The solvent was removed in vacuo to give $0.693 \mathrm{~g} \mathrm{(77 \% )}$ of $\mathbf{1 2}$ as an oil. This was used in the next step without purification. ${ }^{1} \mathrm{H}$ NMR $\left(300 \mathrm{MHz}, \mathrm{CDCl}_{3}\right) \delta \mathrm{ppm} 1.56(\mathrm{~s}, 2 \mathrm{H}) 2.04(\mathrm{~s}$, 2 H) $2.17(\mathrm{~s}, 1 \mathrm{H}) 6.91(\mathrm{~s}, 1 \mathrm{H}) 7.19(\mathrm{~d}, J=4.41 \mathrm{~Hz}, 1 \mathrm{H}) 7.61(\mathrm{~s}, 1 \mathrm{H}) ; \mathrm{MS} 113.1 \mathrm{~m} / \mathrm{z}$ (ESI) $(\mathrm{M}+\mathrm{H})^{+}$.

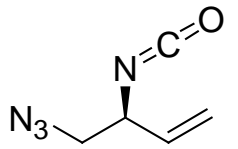

(S)-4-Azido-3-isocyanato-but-1-ene (13). Diphosgene $(0.47 \mathrm{~mL}, 3.93$ mmol) was dissolved in anhydrous $\mathrm{CH}_{2} \mathrm{Cl}_{2}(17 \mathrm{~mL})$ and cooled to $0^{\circ} \mathrm{C}$. It was then treated with a solution containing $12(0.733 \mathrm{~g}, 6.54 \mathrm{mmol})$ and 1,8-bis(dimethylamino)naphthalene $(2.80 \mathrm{~g}, 13.09 \mathrm{mmol})$ dissolved in anhydrous $\mathrm{CH}_{2} \mathrm{Cl}_{2}$ $(17 \mathrm{~mL})$ by slow addition. The reaction was allowed to stir at room temperature for $19 \mathrm{hr}$ then it was concentrated in vacuo. The residue was dissolved in $\mathrm{CH}_{2} \mathrm{Cl}_{2}(50 \mathrm{~mL})$ and washed with $1 \mathrm{~N} \mathrm{HCl}(4 \times 50 \mathrm{~mL})$ followed by $1 \mathrm{~N} \mathrm{NaOH}(1 \times 50 \mathrm{~mL})$. The organic layer was dried $\left(\mathrm{Na}_{2} \mathrm{SO}_{4}\right)$, filtered, and concentrated in vacuo to give $0.80 \mathrm{~g}(88 \%)$ of 13 as an oil. It was used in the next step without purification. ${ }^{1} \mathrm{H} \mathrm{NMR}\left(300 \mathrm{MHz}, \mathrm{CDCl}_{3}\right)$ $\delta$ ppm $3.42(\mathrm{~d}, J=2.71 \mathrm{~Hz}, 2 \mathrm{H}) 5.48(\mathrm{~d}, J=10.51 \mathrm{~Hz}, 1 \mathrm{H}) 7.66(\mathrm{~m}, 1 \mathrm{H}) 7.81(\mathrm{~d}, J=6.78$ $\mathrm{Hz}, \quad 1 \mathrm{H}) \quad 7.94 \quad(\mathrm{~d}, \quad J=8.48 \mathrm{~Hz}, \quad 1 \mathrm{H}) ;{ }^{13} \mathrm{C} \quad \mathrm{NMR} \quad\left(500 \quad \mathrm{MHz}, \mathrm{CDCl}_{3}\right)$ $\delta$ 42.4,113.3, 121.1,122.9; $\mathrm{MS} m / z(\mathrm{ESI}) 138.6(\mathrm{M}+\mathrm{H})^{+}$.

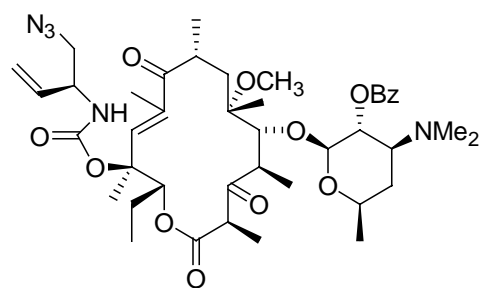

Synthesis of Carbamate (15). Compound 14 (1.77 b, 2.63 mmol) was dissolved in anhydrous $\mathrm{CH}_{2} \mathrm{Cl}_{2}(15 \mathrm{~mL})$ and was then treated with copper (I) chloride $(0.261 \mathrm{~g}, 2.63$ $\mathrm{mmol})$. It was then treated with a solution of $\mathbf{1 3}(0.800 \mathrm{~g}$, $5.79 \mathrm{mmol})$ dissolved in anhydrous $\mathrm{CH}_{2} \mathrm{Cl}_{2}(5 \mathrm{~mL})$ by drop-wise addition. The reaction was stirred at room temperature for $72 \mathrm{hr}$ then more copper (I) chloride $(0.261 \mathrm{~g}, 2.63 \mathrm{mmol})$ was added. Stirring was continued at room temperature $24 \mathrm{hr}$. The reaction was quenched by the addition of sat $\mathrm{NH}_{4} \mathrm{Cl}(50 \mathrm{~mL})$. This was extracted with $\mathrm{CH}_{2} \mathrm{Cl}_{2}(3 \times 25 \mathrm{~mL})$. The 
combined extracts were washed with $\mathrm{H}_{2} \mathrm{O}(1 \times 50 \mathrm{~mL})$ and brine $(1 \times 50 \mathrm{~mL})$. The organic layer was dried $\left(\mathrm{Na}_{2} \mathrm{SO}_{4}\right)$, filtered, and the solvent removed in vacuo. The material was purified using flash chromatography (25 acetone / 75 hexanes / $1 \mathrm{NH}_{4} \mathrm{OH}$ ) to give $1.72(81 \%)$ of 15 as a foam. ${ }^{1} \mathrm{H}$ NMR $\left(300 \mathrm{MHz}, \mathrm{CDCl}_{3}\right) \delta \mathrm{ppm} 0.93(\mathrm{~m}, 6 \mathrm{H})$ $1.16(\mathrm{~m}, 3 \mathrm{H}) 1.31(\mathrm{~m}, 10 \mathrm{H}) 1.49(\mathrm{~d}, J=8.48 \mathrm{~Hz}, 2 \mathrm{H}) 1.55(\mathrm{~d}, J=8.48 \mathrm{~Hz}, 3 \mathrm{H}) 1.77(\mathrm{~m}$, $2 \mathrm{H}) 1.86(\mathrm{~m}, 2 \mathrm{H}) 1.99(\mathrm{~s}, 1 \mathrm{H}) 2.25(\mathrm{~s}, 5 \mathrm{H}) 2.86(\mathrm{~d}, J=6.10 \mathrm{~Hz}, 2 \mathrm{H}) 2.95(\mathrm{~m}, 1 \mathrm{H}) 3.16$ $(\mathrm{m}, 1 \mathrm{H}) 3.45(\mathrm{~m}, 1 \mathrm{H}) 3.60(\mathrm{~m}, 2 \mathrm{H}) 4.14(\mathrm{dd}, J=8.48,3.73 \mathrm{~Hz}, 1 \mathrm{H}) 4.51(\mathrm{~m}, 1 \mathrm{H}) 4.98$ $(\mathrm{m}, 1 \mathrm{H}) 5.26(\mathrm{~m}, 1 \mathrm{H}) 5.75(\mathrm{~m}, 1 \mathrm{H}) 6.78(\mathrm{~s}, 1 \mathrm{H}) 7.42(\mathrm{t}, J=7.46 \mathrm{~Hz}, 2 \mathrm{H}) 7.55(\mathrm{~m}, 1 \mathrm{H})$ $8.02(\mathrm{~d}, J=7.46 \mathrm{~Hz}, 1 \mathrm{H}) ; \mathrm{MS} m / z$ (APCI) $812(\mathrm{M}+\mathrm{H})^{+}$.

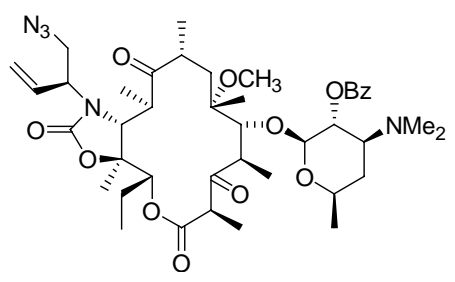

Synthesis of Cyclic Carbamate 3. Carbamate 15 (1.72 g, $2.12 \mathrm{mmol})$ was dissolved in anhydrous THF $(10 \mathrm{~mL})$. This solution was treated with a $1 \mathrm{M}$ solution of $t$-BuOK $(0.068$ $\mathrm{mL}, 0.068 \mathrm{mmol}, 1 \mathrm{M}$ in THF). The reaction was stirred at room temperature for $3 \mathrm{hr}$ then the reaction was quenched with brine $(50 \mathrm{~mL})$. The reaction was extracted with EtOAc $(3 \times 50 \mathrm{~mL})$. The combined extracts were washed with brine $(1 \times 50 \mathrm{~mL})$ and dried $\left(\mathrm{Na}_{2} \mathrm{SO}_{4}\right)$. They were filtered and concentrated in vacuo. Purification by flash chromatography (25 acetone / 75 hexanes / $1 \mathrm{NH}_{4} \mathrm{OH}$ ) gave $1.28 \mathrm{~g}(75 \%)$ of $\mathbf{3}$ as a foam. ${ }^{1} \mathrm{H}$ NMR $\left(300 \mathrm{MHz}, \mathrm{CDCl}_{3}\right) \delta \mathrm{ppm} 0.85(\mathrm{~m}, 2 \mathrm{H}) 0.97(\mathrm{~m}, 5 \mathrm{H}) 1.13(\mathrm{~m}, 3 \mathrm{H}) 1.35(\mathrm{~m}$, $14 \mathrm{H}) 1.65(\mathrm{~m}, 3 \mathrm{H}) 1.78(\mathrm{~m}, 2 \mathrm{H}) 1.90(\mathrm{~m}, 1 \mathrm{H}) 1.98(\mathrm{~m}, 1 \mathrm{H}) 2.05(\mathrm{~m}, 1 \mathrm{H}) 2.30(\mathrm{~m}, 5$ H) $2.68(\mathrm{~m}, 1 \mathrm{H}) 2.83(\mathrm{dd}, J=7.12,5.43 \mathrm{~Hz}, 1 \mathrm{H}) 2.96(\mathrm{~m}, 2 \mathrm{H}) 3.58(\mathrm{~m}, 3 \mathrm{H}) 3.98(\mathrm{dd}$, $J=12.04,9.32 \mathrm{~Hz}, 1 \mathrm{H}) 4.13(\mathrm{~m}, 1 \mathrm{H}) 4.23(\mathrm{~d}, J=8.14 \mathrm{~Hz}, 1 \mathrm{H}) 4.40(\mathrm{~m}, 1 \mathrm{H}) 4.52(\mathrm{~m}, 1$ H) $4.99(\mathrm{~m}, 1 \mathrm{H}) 5.28(\mathrm{~m}, 1 \mathrm{H}) 5.54(\mathrm{~d}, J=17.29 \mathrm{~Hz}, 1 \mathrm{H}) 6.40(\mathrm{~m}, 1 \mathrm{H}) 6.55(\mathrm{~s}, 1 \mathrm{H}) 7.44$ (m, $1 \mathrm{H}) 7.55(\mathrm{~m}, 1 \mathrm{H}) 8.04(\mathrm{~m}, 2 \mathrm{H}) ; \mathrm{MS} m / z(\mathrm{APCI}) 812(\mathrm{M}+\mathrm{H})^{+}$.

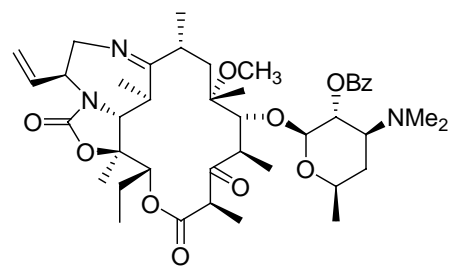

Synthesis of the Tricyclic Erythromycin Analog 4. Compound 3 (1.25 g, $1.54 \mathrm{mmol})$ was dissolved in anhydrous a THF $(25 \mathrm{~mL}) / \mathrm{H}_{2} \mathrm{O}(2.5 \mathrm{~mL})$ mixture. This was treated with triphenylphosphine $(1.94 \mathrm{~g}, 7.39 \mathrm{mmol})$. The reaction was then refluxed for $18 \mathrm{hr}$ and allowed to cool to room temperature. The reaction was concentrated in vacuo. Purification by flash chromatography (30 acetone / 70 hexanes / $1 \mathrm{NH}_{4} \mathrm{OH}$ ) gave $0.614 \mathrm{~g}(52 \%)$ of the cyclized material as a foam. MS m / z (APCI) $768(\mathrm{M}+\mathrm{H})^{+}$. A complete set ${ }^{1} \mathrm{H},{ }^{13} \mathrm{C}$ and 2-dimentional NMR data including DQCOSY, ROESY, HSQC, and gHMBC are shown below. 


\section{Compound 4:}

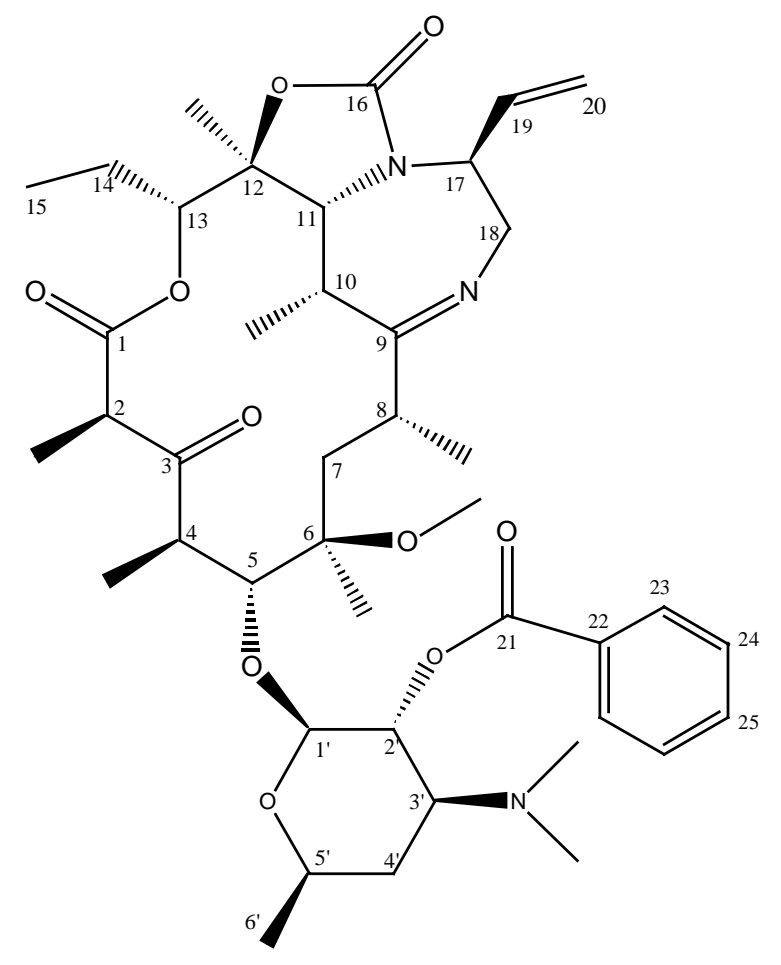

The NMR spectra of the sample 4, including 2D homo and hetero correlation experiments, are consistent with the proposed structure shown in Figure 1. The long range correlation from $\mathrm{H} 18$ to $\mathrm{C} 9$ is clearly observed in HMBC experiment, confirming the cyclized structure from C9 to $\mathrm{C} 11$ and to $\mathrm{C} 18$. The relative stereochemistry at $\mathrm{C} 10$ is consistent with the natural one (shown in Figure 1) based on the following NOE observation: $\mathrm{H} 13-\mathrm{H} 11,12 \mathrm{Me}-10 \mathrm{Me}, \mathrm{H} 10-12 \mathrm{Me}, \mathrm{H} 11-\mathrm{H} 10, \mathrm{H} 10-\mathrm{H} 7$. The relative stereochemistry at C19 is also confirmed by NOE's between pairs of $\mathrm{H} 19-\mathrm{H} 11, \mathrm{H} 18$ $10 \mathrm{Me}$ and $\mathrm{H} 19-6$ OMe.The proton and carbon assignments of the compound 70549-5-1 are made from 2D NMR experiments, and listed in the appended table.

\begin{tabular}{|l|l|l|l|}
\hline Position & Group & $\mathbf{1 3 C}$ & $\mathbf{1 H}$ \\
\hline 1 & $\mathrm{C}=\mathrm{O}$ & 169.2 & -- \\
\hline 2 & CH & 51.1 & 3.70 \\
\hline $2 \mathrm{Me}$ & CH3 & 15.1 & 1.31 \\
\hline 3 & C=O & 204.4 & -- \\
\hline 4 & CH & 46.8 & 2.97 \\
\hline $4 \mathrm{Me}$ & CH3 & 14.6 & 0.98 \\
\hline 5 & OCH & 77.2 & 4.32 \\
\hline 6 & OC & 78.4 & -- \\
\hline $6-\mathrm{OMe}$ & OCH3 & 50.8 & 2.70 \\
\hline $6 \mathrm{Me}$ & CH3 & 20.0 & 1.32 \\
\hline 7 & CH2 & 38.2 & $1.51,1.44$ \\
\hline
\end{tabular}




\begin{tabular}{|l|l|l|l|}
\hline 8 & CH & 42.7 & 2.68 \\
\hline $8 \mathrm{Me}$ & CH3 & 20.3 & 1.04 \\
\hline 9 & C=N & 181.9 & -- \\
\hline 10 & CH & 35.5 & 2.75 \\
\hline $10 \mathrm{Me}$ & CH3 & 10.9 & 1.21 \\
\hline 11 & NCH & 57.6 & 3.73 \\
\hline 12 & OC & 81.4 & -- \\
\hline $12 \mathrm{Me}$ & CH3 & 13.5 & 1.44 \\
\hline 13 & OCH & 77.1 & 4.86 \\
\hline 14 & CH2 & 22.3 & $1.91,1.51$ \\
\hline 15 & CH3 & 10.3 & 0.83 \\
\hline $1^{\prime}$ & OCHO & 101.6 & 4.54 \\
\hline $2^{\prime}$ & OCH & 72.1 & 5.04 \\
\hline $3^{\prime}$ & NCH & 63.6 & 2.84 \\
\hline $3^{\prime}-\mathrm{NMe}$ & NCH3 & 40.7 & 2.26 \\
\hline $4^{\prime}$ & CH2 & 31.4 & \\
\hline $5^{\prime}$ & OCH & 69.2 & 3.62 \\
\hline $6^{\prime}$ & CH3 & 21.0 & 1.29 \\
\hline 16 & C=O & 156.0 & -- \\
\hline 17 & NCH & 53.6 & 4.75 \\
\hline 18 & NCH2 & 52.3 & 3.97 \\
\hline 19 & $=$ CH & 134.2 & 5.88 \\
\hline 20 & $=\mathrm{CH} 2$ & 118.5 & $5.37,5.21$ \\
\hline 21 & C=O & 165.1 & -- \\
\hline 22 & $=$ C & 130.6 & -- \\
\hline 23 & $=$ CH & 129.8 & 8.03 \\
\hline 24 & $=$ CH & 128.3 & 7.44 \\
\hline 25 & $=$ CH & 132.7 & 7.57 \\
\hline & & & \\
\hline
\end{tabular}




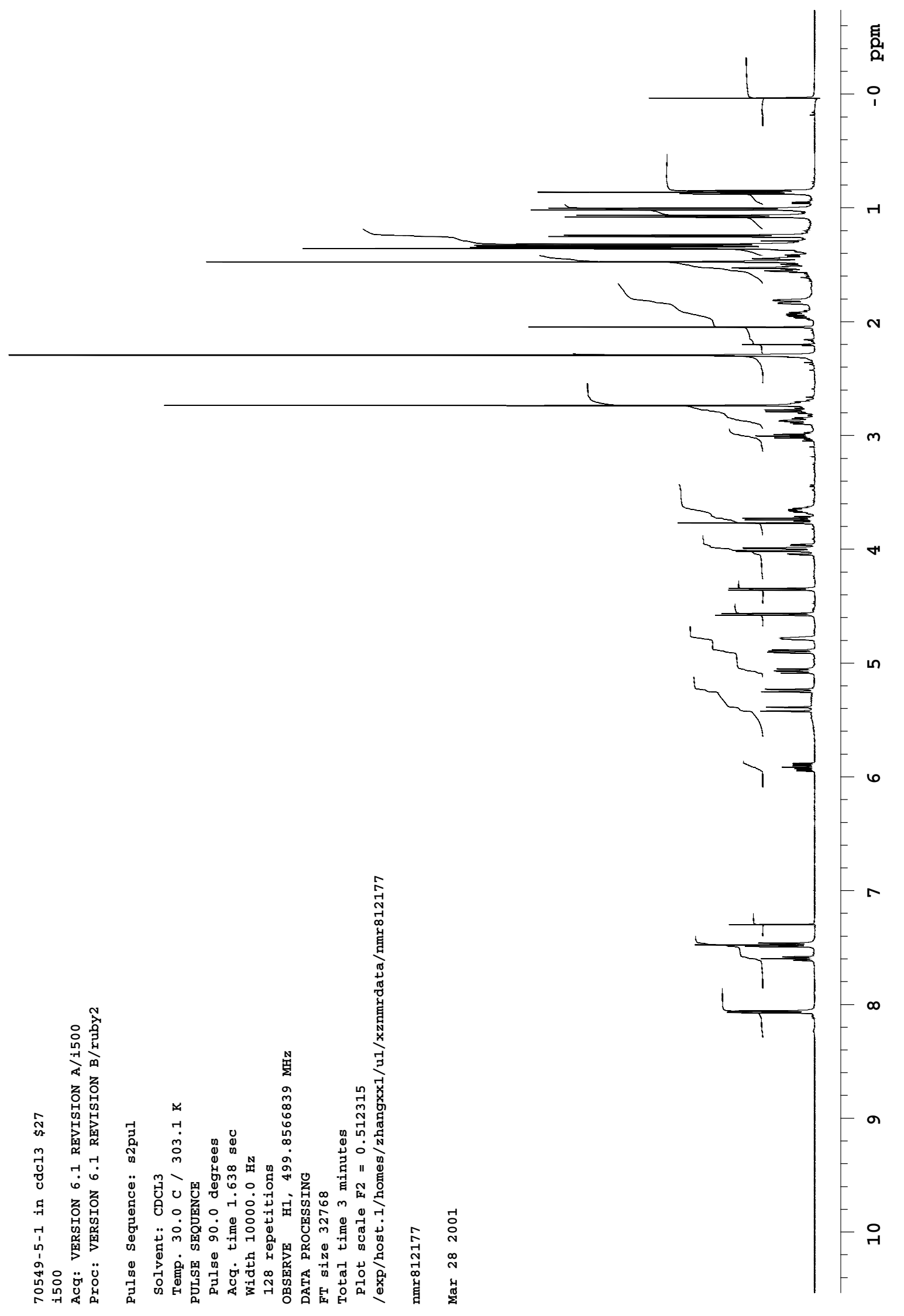




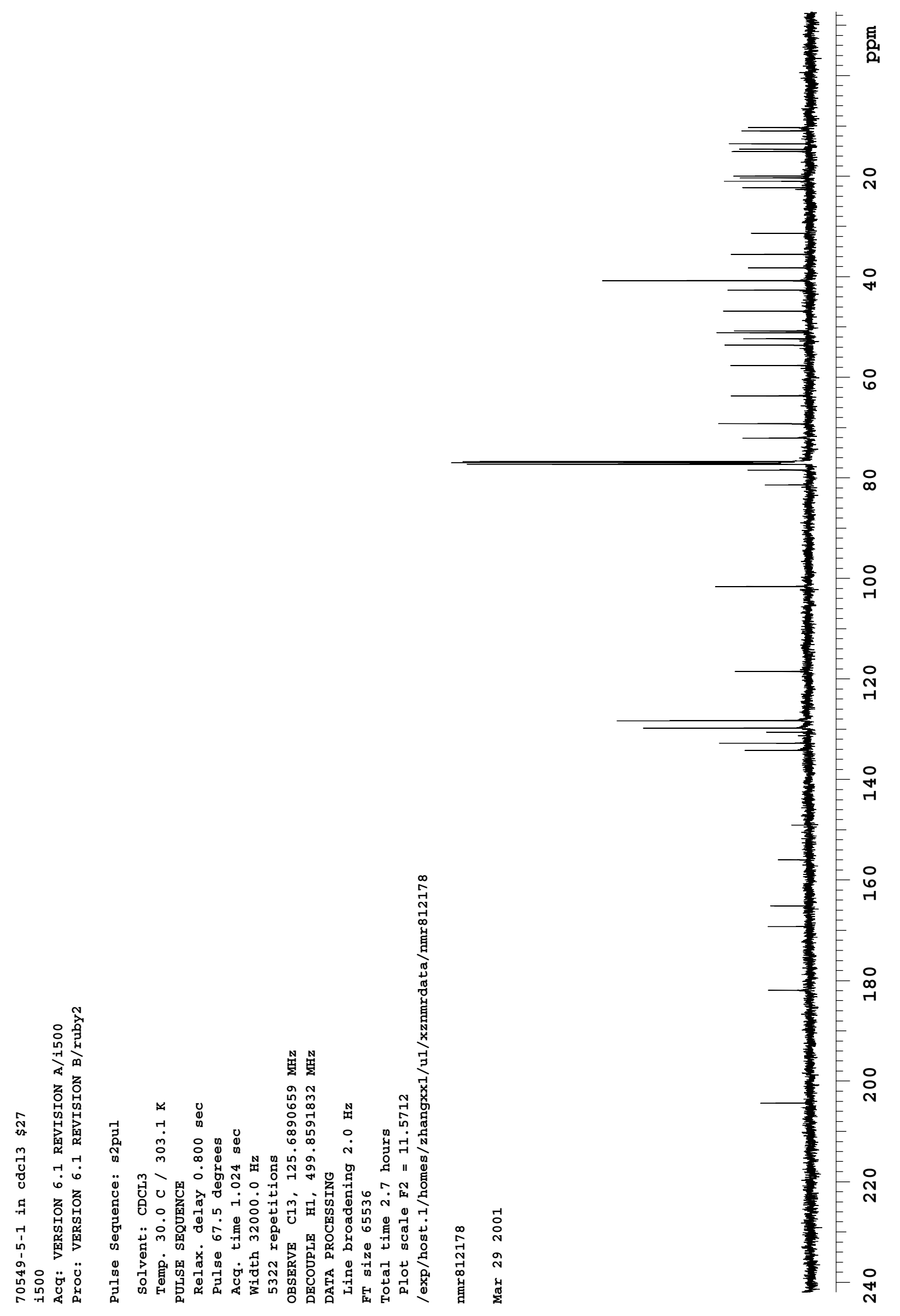



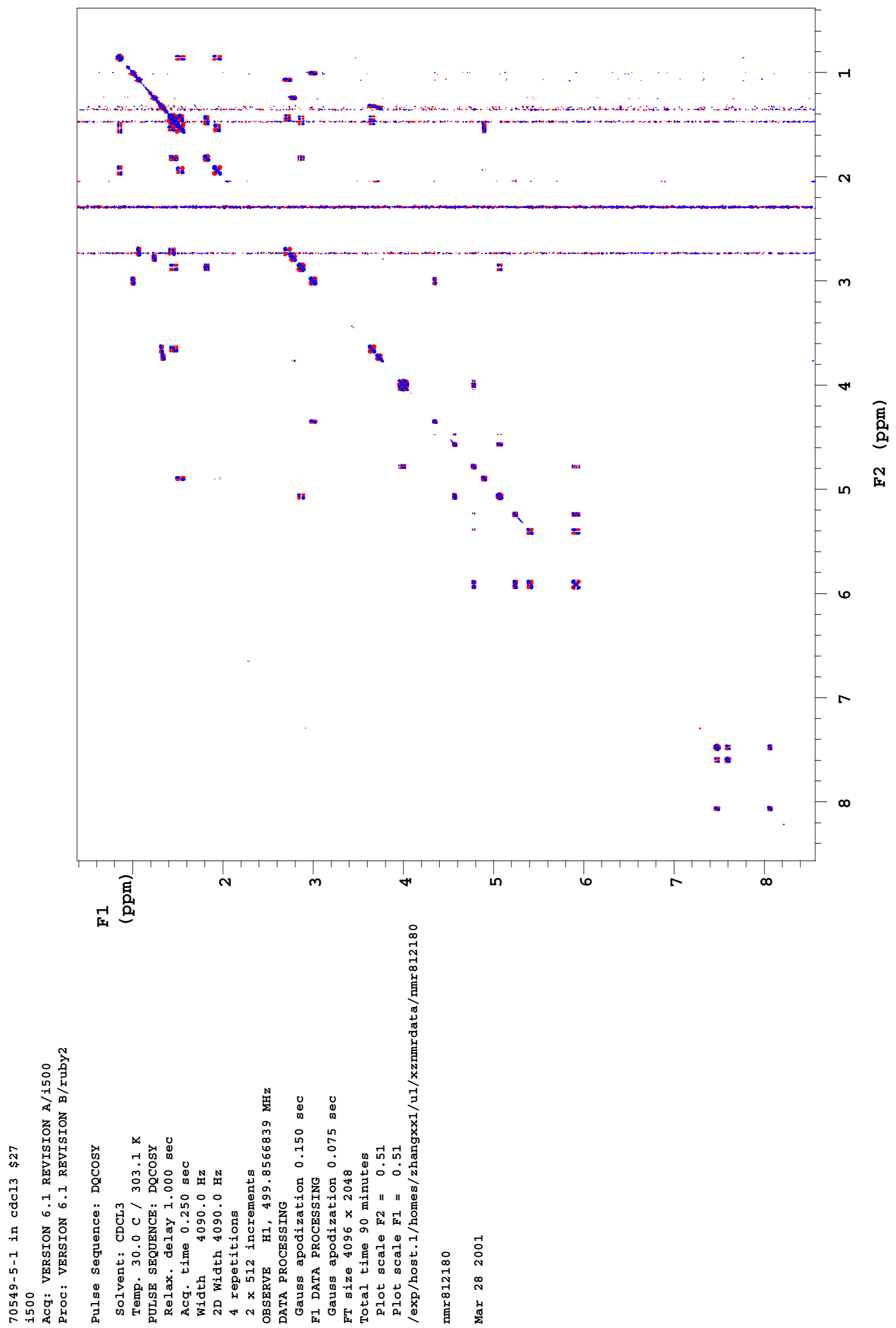

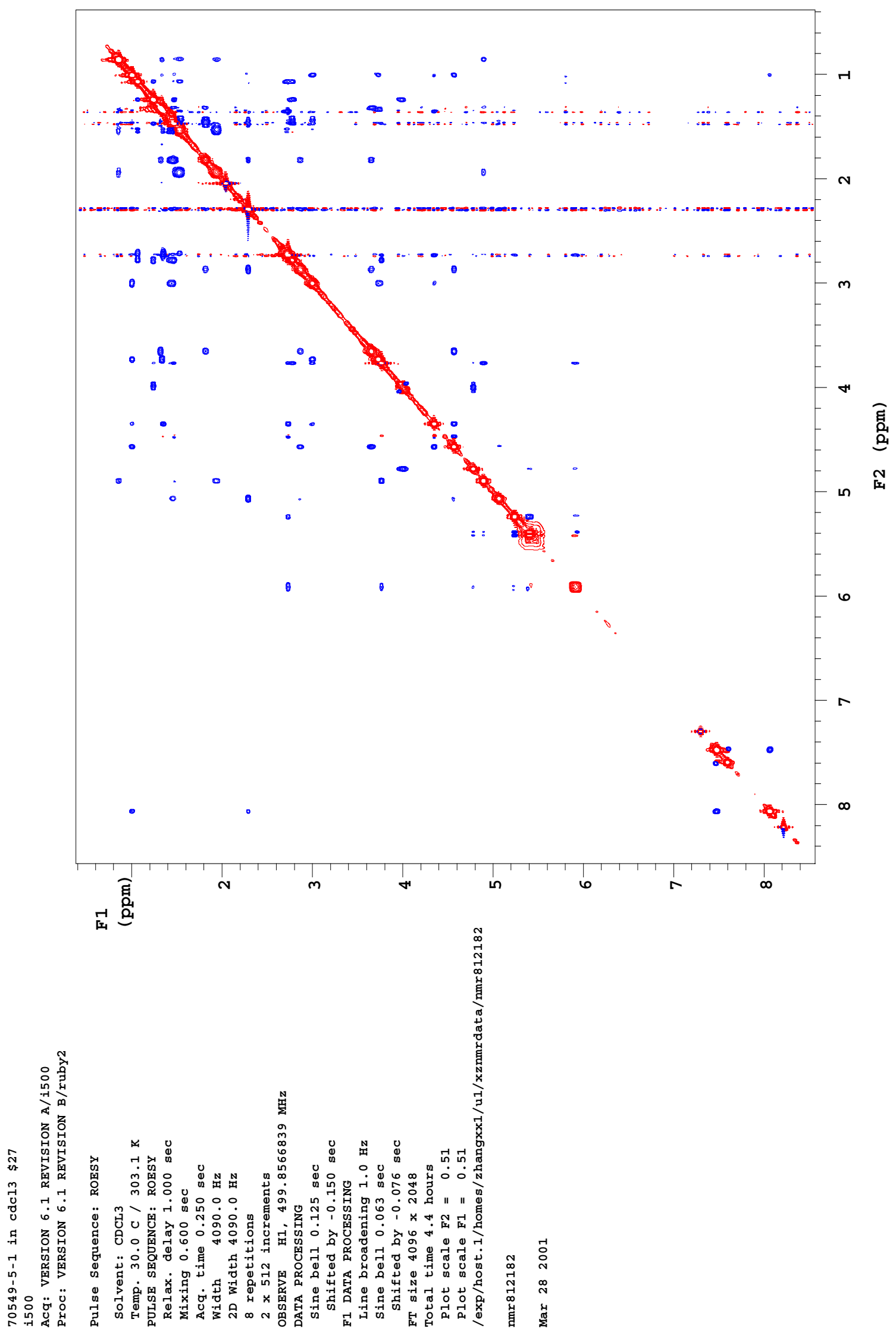

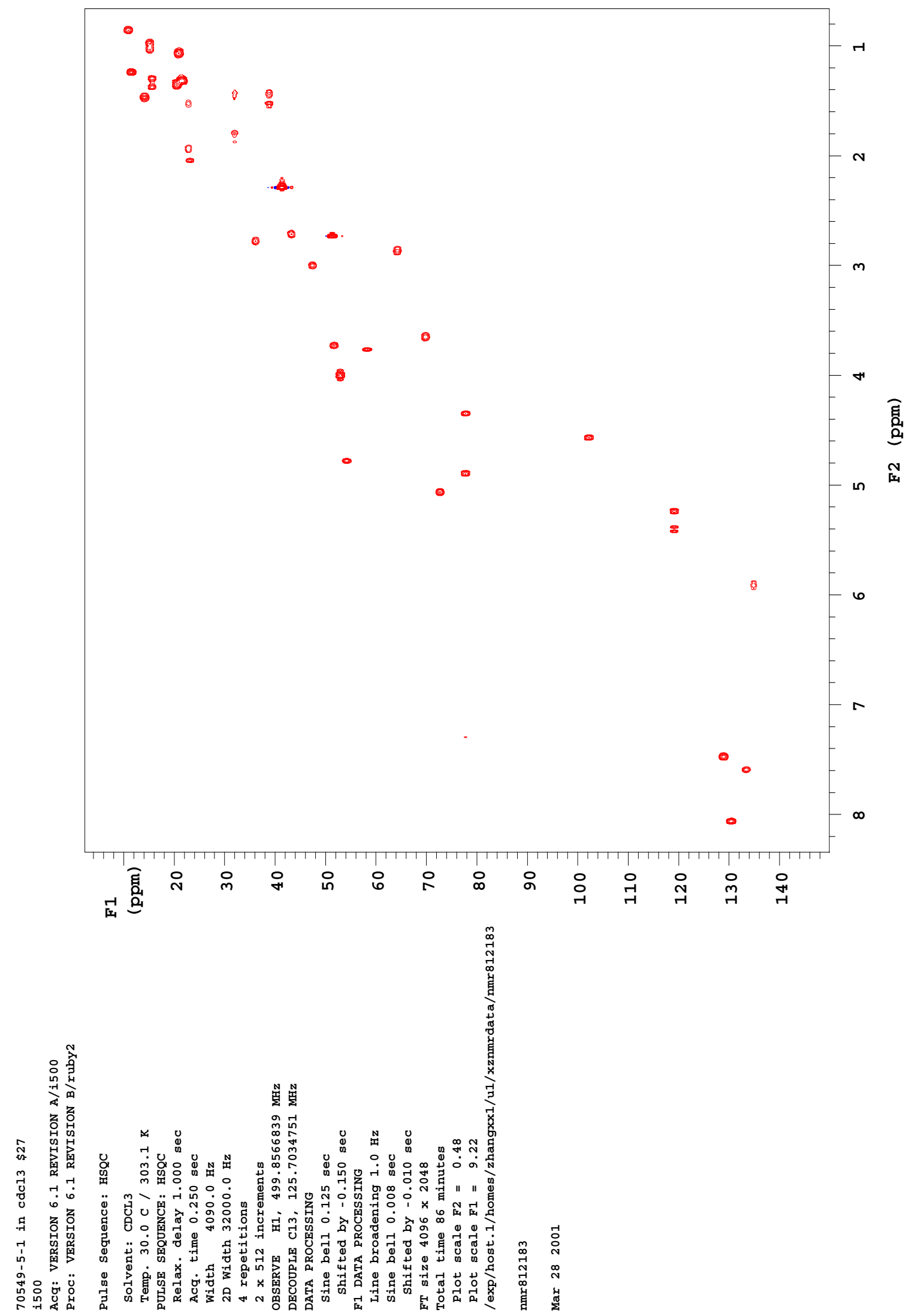

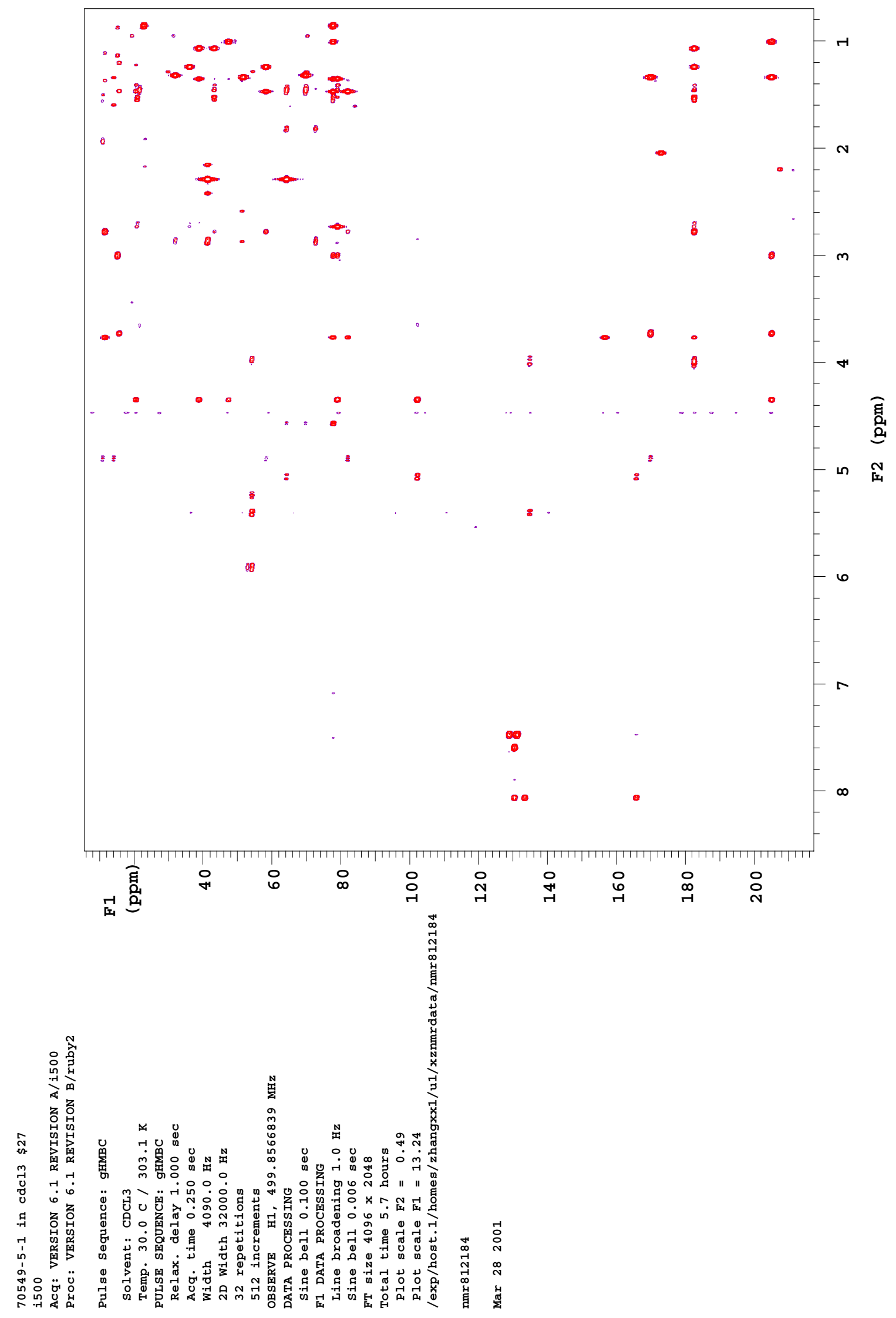